\title{
A MAGYAR GAZDASÁGPOLITIKA 1989 ÉS 2019 KÖZÖTT
}

Bod Péter Ákos

A magyar gazdaság átalakulását rendkívül erősen meghatározták az 1989/199o-es rendszerváltozás és a rákövetkező időszakok mozgalmas társadalmi és politikai eseményei. Hazánk az európai piacgazdasági rendbe részleges monetizáltsággal, túlméretezett iparral és elhanyagolt infrastruktúrával lépett be. A külső eladósodottság és a nyugati politikai rendszerhez való végérvényes csatlakozás szándéka dominálta sokáig a gazdaságpolitikát, miközben a társadalmi elvárások középpontjában a fejlett Nyugathoz való jövedelmi közeledés állott. A piacgazdasági intézményrendszer kiépítése és a nyugati ipari értékláncokba való bekerülés sikerrel járt, a jövedelmi konvergencia azonban egyenetlen és lassú, ami széleskörủ frusztráció okozója. A pénzügyi válság exponálta a nagyfokú kereskedelmi és pénzügyi nyitottságból fakadó kockázatokat. A rákövetkező időszak nem szokványos gazdaságpolitikáinak és külső okok egymásra hatásának nyomán csökkent a külső kitettség. Az egyre erősödő centralizáció és a szuverenitásnövelő kormánypolitika azonban megnöveli az uniós intézményekkel való ütközések gyakoriságát. A felzárkózást gyorsítani szándékozó gazdaságpolitikák ellenére a közepes fejlettségi státusz tartóssá vált, ami a külső és belső elvándorlást erősíti, a területi feszültségeket növeli. Az áru- és munkaerőpiacok új jelenségei és a technológiai trendek a magyar gazdaságpolitika elé új feladatokat állítanak, továbbá bonyolult alkalmazkodási teendők adódnak a folyamatban levő európai hangsúlyváltásokból.

JEL-kódok: E02, E44, E6o, F15, 43

Kulcsszavak: rendszerváltozás, piacgazdasági intézmények, KGST-együttműködés, kétszintű bankrendszer, európai integráció, makrogazdasági stabilizálás, munkatermelékenység

\section{HELYÜNK: EURÓPA PEREMVIDÉKÉN}

\section{1. Állandóság a változások közepette:} közepes fejlettség, magasabb aspiráció

A magyar gazdasági viszonyok e három évtized alatt rengeteget változtak, értelmezésükhöz azonban ki kell lépnünk a gazdasági tények és adatok világából, elismerve az egymást követő politikai fordulatok fontosságát. Már maga az európai térkép is más e sorok írásakor, mint volt az időszak kezdetén. A Magyar 
Népköztársaságot 1989-ben öt szomszéd határolta, abból három (Csehszlovákia, Jugoszlávia, Szovjetunió) hamarosan megszünt. Az ország akkor NATO-ellenes katonai szövetségnek és szovjet irányítású termelésszakosítási szervezetnek volt a tagja, majd mind a Varsói Szerződés, mind a KGST feloszlott. Hazánk azóta részese a nyugati szövetségi rendnek és az európai integrációnak.

Valamennyi kelet-közép-európai ország fejlődését rendkívül erős kül- és geopolitikai meghatározottság jellemzi, ám a térség még a hidegháborús időkben sem vált homogén blokká társadalmi-gazdasági vonatkozásokban. Nemzetei 1990 után sokban eltérő gazdaság- és szociálpolitikai utakat választottak, holott az EU tagjelöltjeként, majd tagjaként mindegyik erős intézményi harmonizáláson esett át. Mégis markánsan különbözik például Észtország és Románia vagy Szlovénia és Magyarország. A fejlettségi és szerkezeti különbözőségek, a nemzeti sajátosságok ismeretében könnyebb megérteni a bejárt pályát, és előre jelezni a jelenkor kihívásaira adható válaszokat.

A befutott pályánk értékeléséhez nem saját múltbeli helyzetünk, inkább más nemzetek teljesítménye az objektív mérce. Ám nem magától értetődő, hogy melyik az adekvát keret a magyar gazdasági pálya és gazdaságpolitikai gyakorlat megítéléséhez, azon túl, hogy az 1989/199o-es fordulat óta sokakkal együtt a posztkommunista társadalom, tranzíciós ország és egykori tervgazdaság elnevezés alatt tartják számon Magyarországot. Mindez viszont egyaránt alkalmazható az NDK, Szerbia vagy Lengyelország esetére is, holott gazdaságpolitikai pályánk három évtizedének értelmezésénél közvetlenül csak a legutóbbi releváns. A benchmark nem jelölhető ki tetszőlegesen, de nem is vezethető le kizárólag objektív mutatókból: a társadalmi érzületet is figyelembe kell venni. A magyar közvélemény hagyományosan Ausztriát, Németországot tekinti legfőbb hozzámérési pontnak, és máig nem szívesen viszonyít mondjuk Romániához, pedig a gazdasági fejlettség és a gazdaságpolitikai mozgástér alapján az relevánsabb, mint a történelmileg érthető, de nem reális ausztriai mérce.

Magyarországot a piacelemzők, nemzetközi szervezetek jelenleg a humán fejlettség (HDI) szerint a világ felső, a jövedelmi szint szerint inkább felső-közepes csoportjához, piaci megítélésben a felemelkedő (emerging) gazdasági kategóriához sorolják. Geopolitikai értelemben az európai peremvidékhez tartozunk. Itt e kategóriákat elfogadjuk, és a három évtizedes pályára is alkalmazzuk.

\subsection{Máig kiható gazdaságtörténelmi előélet}

A magyar kapitalizmus a világ akkori magországaihoz képest bizonyos késéssel fejlődött ki, ám fontos látni, hogy gazdaságunk a kapitalizálódás idején nem minösült elmaradottnak. A 19. században a Nyugat-Európához mért fejlettségi szintkülönbség jelentős volt, de nem zárta ki a felzárkózás esélyét. A hitelintézeti 
szektor, a tőzsde, az integrált vasúti közlekedési rendszer, a tulajdoni kataszter, a kereskedelmi és pénzügyi jog, valamint a kapitalista rend számos egyéb fontos intézménye a korszak európai normáinak megfelelően kiépült. A piaci fejlődéshez egy nagyobb entitás, az Osztrák-Magyar Monarchia szolgált keretül. A Monarchia egy grádiccsal elmaradt fejlettségben Európa nyugati felétől, és politikai evolúciója sokban különbözött azétól, például kimaradt a tengerentúli gyarmatosításból, ám a magyar gazdaság számára egészében véve ösztönző integrációs keretnek bizonyult a technológiához, tőkéhez és piachoz való hozzáférést tekintve. A Magyar Királyság jövedelmi szintje ugyan a Monarchia fejlettebb tartományaiban tapasztaltnak csupán kétharmadát érte el, a gazdaság viszont gyorsan növekedett; ekkora relatív növekedési többletet azóta sem értünk el, különösen nem az itt áttekintett 30 év során.

Az európai hatalmi viszonyok alakulása lezárta a korszakot 1918-ban. A két világháború között Magyarország immár politikailag szuverén. Közepesen iparosodott gazdaságot mondhatott magáénak, amely azonban politikai és gazdaságszerkezeti okokból erősen függött a német, osztrák, olasz felvevőpiacoktól. Hazánk a második világháború után újabb kényszerpályára került, korlátozott szuverenitással. Újjáépítési és modernizációs pályáját ismét külső erők határozták meg: a keleti blokkba sorolódott. A gazdasági szerkezetet determinálta az egypárti politikai szisztéma és a hidegháborús logikájú, erőltetett iparosítás.

Mindmáig sok minden áthagyományozódott ebből az előéletből. Amit külön érdemes exponálni, az a magyar társadalom- és gazdaságpolitikát máig átható utolérési törekvés és az osztrák-német szinthez való viszonyitás. Ez történelmileg érthető, azonban táplálója a magyar társadalom tartós frusztráltságának, hiszen míg Európa keleti fele és benne hazánk 1945-től egy nálunk gazdaságilag fejletlenebb, militarizált nagyhatalom érdekövezetébe került, az idő alatt a nyugati államok a nemzeti megosztottságon jórészt felülemelkedve integrációs pályára léptek, $s$ Ausztria, Németország még a gyorsan emelkedő nyugati átlagot is felülmúló jövedelmi szintre jutott. Ezáltal a hozzájuk mért fejlettségi elmaradásunk tovább nőtt a 20. század második felében. Az előbbiek globális mércén mérve magországok, a mai Magyarország pedig peremhelyzetű, amint az volt az előző gazdaságtörténeti időszakokban is.

Különlegesen bonyolult gazdaságpolitikai kihívások fakadtak abból, hogy e harmincéves időszak derekától a magyar államra egyidejűleg vártak az európai peremhelyzetből, az „emerging market” mivoltunkból fakadó, sajátos feladatok, miközben már az EU-tagsággal járó lehetőségek és kötelezettségek is munkát adtak. 


\section{A RENDSZERVÁLTOZÁS GAZDASÁGPOLITIKÁI}

\subsection{Rendezett politikai átmenet 1989/1990-ben - a gazdasági csőd közelében}

A térségben az 1989-90-es politikai fordulatot közvetlenül a geopolitikai viszonyok hirtelen átalakulása idézte elő, de a gazdaság állapota is jelentősen befolyásolta a politikai rendszer megváltozását és annak módját. Magyarországon az állampárt (MSZMP) addigra belátta, hogy a régóta felgyülemlő szerkezeti gondok és különösen az akut pénzügyi bajok nem oldhatók meg a fennálló intézményi-politikai keretek között, a megszokott reformálási-kiigazítási technikákkal gyökeres változtatáshoz viszont nem maradt legitimációja. 1989 végén Magyarország nemzetközi fizetőképessége is kétségessé vált a hitelezők, tőkepiaci partnerek szemében. Az IMF-fel 1982 óta állott fenn az országnak tagsági viszonya és hitelkapcsolata; azt azonban rosszul érintette a belépés óta folytatott adatmanipuláció (misreporting) felszínre kerülése 1989 végén.

A pénzügyi csőd közeledte az Ellenzéki Kerekasztal alkotmányos követeléseinek elfogadására ösztönözte az államhatalmat. 1990 tavaszára kiírták a szabad választásokat. Akkor egyébként úgy látszott, hogy az állampárt osztódása utáni nagyobb utódpárt (MSZP) esélyes a relatíve legerősebb parlamenti pozíció megszerzésére. A politikai dinamika azonban másként alakult: a szocialisták az országgyülési helyeknek csak a tíz százalékát szerezték meg, a főhatalom a jobbközép irányultságú MDF és a politikai spektrum baloldali-liberális térfelén elhelyezkedő SZDSZ közötti szoros küzdelemben dőlt el. Az MDF alakított kormányt 1990 áprilisában a Kisgazdapárttal és a kereszténydemokratákkal együtt, míg a parlamenti ellenzéket a szabaddemokraták, az akkor liberális-alternatív Fidesz, valamint az MSZP alkotta. A politikai rendszerváltozás a térségben talán a legrendezettebb lett, eltekintve Németország különleges esetétől, ahol a keleti tartományok rövid úton átkerültek a nyugatnémet politikai, jogi és gazdasági rendbe, és ezzel átmenet nélkül az európai gazdasági közösségbe is.

A rezsimváltás nemcsak a térségben hirtelen megszaporodó krízisekhez képest látszott sikeresnek. Az alkotmányos rend teherbíró képességét tanúsítja a négyévenkénti országgyűlési választási ciklusok szabályszerüsége, valamint haláleset (Antall József, †1993) vagy politikai ok miatti (Medgyessy Péter, 2004; Gyurcsány Ferenc, 2009) miniszterelnök-váltások rendezettsége. A magyar közjogi berendezkedés egészében véve előnyt jelentett a gazdasági fejlődés szempontjából.

Ugyanez viszont nem mondható el a megörökölt gazdasági szerkezetről, amely a kedvező nemzetközi megítélés és a hazai közvélemény várakozásai ellenére nem bizonyult jobbnak a térség többi országáénál. A strukturális problémák részben ismeretesek voltak a döntéshozói körökben és valamelyest a nagyközönség előtt 
is, más vonatkozások viszont fokozatosan tárultak fel a rendszerváltozási folyamatban. Amit tudni lehetett: bár a „vas és acél országa” gazdaságpolitikai szakasz még az államszocializmus első felére esett, ám minden későbbi reformálás ellenére túlméretezett nehézipar, nehézvegyészet, bányászat, hadiipar maradt hátra. Ez az örökség olyan nagy erőforrás-igényü térségi és ágazati válságkezelést tett volna szükségessé a rendszerváltás idején, mint amilyet Nyugat-Európa az 1970es évek során már végrehajtott. Erre azonban 1990 után nem volt pénz. Sőt, ehhez még hozzáadódott egy legalább ennyire súlyos, általános örökség: a szocialista iparban, mezőgazdaságban a gyenge-közepes minőségű, korlátozottan piacképes termelés dominanciája, a szolgáltatások és az infrastruktúra elmaradottsága.

A széleskörű minőségi-piacképességi elmaradás részben az addigi nemzetközi betagozódásból eredt. A gépipar, élelmiszeripar, könnyűipar, gyógyszergyártás és más nagyfoglalkoztató ágazatok termékskáláját az 1960-es évektől torzította a politikai szempontokon, nem pedig a komparatív előnyök logikáján alapuló KGST-szakosodás. A KGST megszünésével 1990-ben eltünt az érintett termelési kultúrák létalapja. A keleti szabványok és igényszint szerint gyártott termékeket más külső piacokon nem lehetett gazdaságosan elhelyezni, a hazai kereslet pedig elégtelen volt a kapacitások fenntartásához.

A minőség ügye az egész politikai-gazdasági rendszerben gyökerezett. A működési zavarok már az 1950-es évektől jelezték, hogy a rendszer alapintézményének számító állami nagyüzem a nagyszériás, homogén, közepes minőségű termékeknek kedvez, míg gátja a rugalmasságnak, innovációnak, versenyképességnek. Szovjet-orosz viszonyok között a tömegtermelés felfutása is járhat modernizációs hatással, ám hazánk számára ez a termelési kultúra történelmi visszalépést jelentett. Az időközben lezajló nyugat-európai „gazdasági csodák” fényében a centralizált tervezés zsákutcás természete kezdett szembetűnővé válni úgy Magyarországon, mint más, viszonylag fejlett szocialista országokban.

E felismerésre reagált a vállalati önállóságot kiterjesztő „Ujj Gazdasági Mechanizmus" 1968-tól. Hozott is bizonyos eredményeket: a vállalati vezetés rugalmasabbá és keresletérzékenyebbé vált. Az állami nagyüzem és az együttmüködő kisszervezetek együttéléséből különös hibrid formák jöttek létre, amelyek föleg a mezögazdaság és a szolgáltatások néhány ágazatában váltak be - amíg a nagyvállalatok léteztek. Amikor viszont azok a gyors külgazdasági nyitást követően versenyképtelenségük okán megszüntek vagy szétdarabolódtak az 1990-es évek legelején, a velük szimbiózisban élő protovállalkozások is gyakran elenyésztek.

A magyar ipari termelés növekedése már a tervgazdaság utolsó szakaszában, a külpiacok szigorodásának és a versenyképesség romlásának együttes hatására leállt, amire válaszként a rezsim az ötven legnagyobb (és így politikailag érzékeny) vállalatot különleges elbánási szándékkal kiemelte, mintegy a „too big to fail” korabeli megnyilvánulásaként. A rendszerváltozás után azonban sem anyagi erő, 
sem szándék nem volt, a nemzetközi kötelezettségek miatt lehetőség sem maradt a hazai gazdaság ekkora részének preferenciális kezelésére.

Mégis, az 1990 utáni gyors ipari termeléscsökkenés nyomán, és ismerve a lassan piacosító Kína, Vietnám termelési dinamikáját, felmerül a kérdés: nem lett volna-e jobb időt adni a hazai vállalkozásoknak a felkészülésre, lassítani a külpiaci nyitást? A válaszhoz szükséges rátekinteni a makrogazdasági viszonyokra, az állam eladósodottságára, a gazdaság szerkezeti ügyeire, majd a tárgyalt korszak gazdaságelméleti, gazdaságideológiai kötöttségeire.

\subsection{Mulasztások és adósságok felszínre kerülése}

A piacgazdasági rendre való rendezett visszatérés egyik legkomolyabb, a politikai közéletet erősen foglalkoztató tehertétele Magyarország súlyos államadóssága volt, ami jórészt külföldi hitelezőkkel szemben, devizában állt fenn. A más országok fizetőeszközében való eladósodás („eredendő bűn” a fejlődésgazdasági szakirodalomban) a népköztársaság esetében abból fakadt, hogy az országon belül nem keletkezett akkora pénzmegtakarítás, amely az ikerdeficitet (az állami költségvetés folyamatos hiányát és a fizetésimérleg-hiányt) finanszírozhatta volna.

Az 1970-es és 80-as évek külkereskedelmi mérleghiányát szállítói hitelekkel, majd fokozatosan finánchitelekkel és devizakötvény-kibocsátással finanszírozták. A pénzpiaci feltételek hirtelen megnehezedtek az 1970-es évek legvégén, ami a magyar pártvezetést a Nemzetközi Valutaalapba és a Világbankba való belépésre sarkallta. A tagsági feltételek vállalásával és további reformok ígéretével 1982-t követően ezektől további forrásokhoz lehetett jutni, így viszont az eladósodási folyamat is folytatódott.

Az 1990-es szabad választások előtt a kormány népszerűségnövelő intézkedéseket hozott, így megemelte a turistaútra felvehető valutakeretet, amelyet sokan - az importkorlátozás világában - magánimport céljából váltottak ki. Ezzel viszont kritikus szintre esett az ország devizatartaléka. Az 1990-es tavaszi választások idején euróra átszámolva 16 milliárdra rúgott Magyarország összes külföldi tartozása, amellyel szemben mindössze 875 millió eurónyi nemzetközi tartalék állott konvertibilis devizákban - ez mindenképpen elégtelen mérték, különösen annak ismeretében, hogy a rövid lejáratú (éven belüli) devizahitelek állománya a tartaléknak csaknem háromszorosa volt. A hivatalba lépő Antall-kormány így roppant mód rá volt utalva az IMF-fel való együttműködésre, a nemzetközi tőkepiac bizalmára. Mindez nagyban behatárolta az első szabadon választott kormány gazdaságpolitikai mozgásterét.

Érhető, hogy e hatalmas induló nehézségek ismeretében tartós vitatéma az államcsőd elkerülésére törekvő gazdaságpolitika. A külső adósságról azonban 
mindmáig téves narratívák élnek a közvéleményben. Egyesek az 1982-ben államcsődöt jelentő Lengyelország még folyamatban levő átütemezési tárgyalásainak lemásolását kérték számon a teljesen más jogi és tartalmi viszonyokat menedzselő Németh-kormányon, majd az Antall-kormányon. Volt olyan várakozás is, hogy a történelmi érdemekre tekintettel a Nyugat leírja a tartozásokat. Sőt élt olyan legenda, mely szerint kedvezményeket lehetett volna kapni, ha kérjük. Ezek alaptalan spekulációk. A Nyugat politikai köreiből érkező biztatások és általános támogatási ígéretek ellenére hamar nyilvánvalóvá vált, hogy átfogó adósságkönnyítésre a régió országai nem számíthatnak, a nagyon eltérő helyzetű, volt tervgazdaságoknak saját adottságaik szerinti, egyéni stratégiákat kell találniuk. Időközben az addigi néhány rendszerváltó ország helyett a szocialista tömb szétesése folytán sok új szereplő jelent meg a politikai és nemzetközi pénzügyi porondon; átmenetük megsegítésére nemzetközi fejlesztési bank (EBRD) alapításával, az IMF térségbeli aktivitásának növelésével reagált a nemzetközi közösség. Adósságkönnyítés a magyar esetben komolyan nem jött szóba, az olyan manőverek pedig, amelyek nyomán odaveszett volna a fizetőképesség, a sikeresen induló és ígéretes átmenetet súlyosan kockáztatták volna.

A téveszmék és alaptalan remények megnehezítették a kormányzati adósságkezelő munkát azzal, hogy az egyébként szolvens Magyarországról is fel-felröppentek olyan hírek, amelyeket a fizetési hajlandóság ingatagságaként értelmezhettek a tőkepiacokon. Holott a pontos fizetés stratégiája középtávon eredményes lett. Hosszabb lejáratú és kedvezőbb kamatozású források bevonásával, a privatizációs bevételekkel és a közvetlen tőkebefektetés (FDI) nekilendülése révén az ország külső tartozásának szerkezete gyorsan átalakult. Időközben a háztartások megtakarítói pozíciói jelentősen javultak, a hazai szereplők részaránya megnőtt a költségvetési hiány finanszírozásában a bankszektoron keresztül. A következő, 1994-esországgyülési választás idején az MNB feltöltött devizatartaléka szavatolta a kormányváltás miatti esetleges piaci aggodalmak semlegesítését: a nemzetközi tartalékok 5,4 milliárd eurónak megfelelő szintre nőttek, miközben a rövid lejáratú külföldi tartozás 2 milliárd alatt maradt.

A gazdaság exportképessége folyamatosan javult, a fizetési mérleggel kapcsolatos gondok mérséklődtek, és az ország egy évtized alatt túljutott a külső adósság és a belső államadósság nehéz szakaszán. Olyannyira, hogy a kétezres évek legelején, az euró átvételének korai latolgatása idején a GDP-hez mért államadóssági arány (akkor 52\%) lett az egyetlen maastrichti mutató, amelyet hazánk teljesíthetett volna. Ennek jelentőségét annak fényében is megítélhetjük, hogy 2018-ban jóval 7o százalék fölött állt a mutató az állami költségvetést tehermentesítő, uniós eurómilliárdok hosszú évek óta tartó beáramlása ellenére.

Ugyanakkor a rendszerváltozás első évei nagy szerkezeti elmaradásokat és mulasztásokat hoztak felszínre. A reformszocialista időszak szimulált piaci ver- 
senye az erőforrások észszerübb, takarékosabb felhasználását ígérte, ám 1990 megmutatta, hogy a megreformált magyar gazdaság munkatermelékenységi, energiaigényességi, tőkehatékonysági öröksége nem lényegesen jobb, mint amit a merev központi tervezésű Csehszlovákia vagy a válságok sújtotta Lengyelország hagyott hátra. Egységnyi (egy dollárra vagy egy német márkára jutó) termeléshez e régióban a nyugat-európaiénál többször nagyobb energiafajlagos tartozott a piaci nyitás pillanatában; ebben csak annyival volt jobb a magyar helyzet, amenynyivel kisebb lett addigra az országban a nehézipar aránya. Az állami szubvenciók megszűnésével és a világpiaci árakra való áttéréssel a vállalkozások számára 1990-től hirtelen megdrágult az energia, ami egész ágazatok versenyképtelenségét hozta felszínre. Hiába voltak alacsonyak a térségben a munkabérek, az adott hatékonysági, termelékenységi fajlagos adatok mellett a versenynek kitett állami vállalatok, frissen privatizált cégek a reméltnél sokkal rosszabban szerepeltek.

A pénzintézeti szektor is olyan terület, amely csalódást okozott a várakozásokhoz képest. E téren ugyan a magyar reformszocializmus nyitottabb volt, mint (Jugoszlávia kivételével) a térség, hiszen nálunk már az 1980-as években megjelenhettek vegyes tulajdonú vagy teljesen külföldi hátterü bankok, és az IMF/Világbank ösztönzésére létrejött (pontosabban helyreállt) a kereskedelmi banki szint. A kétszintü bankrendszer helyreállításának gondokkal teli menetét ehelyütt nem fejtjük ki, ám néhány gazdaságpolitikai következményt fontos megemlíteni.

A szektor bajai leginkább a négy évtizedes tervgazdasági rendből eredtek: ilyen a kellő szakértelem hiánya mind a bankári, mind az ügyféloldalon, a jogi keretek kialakulatlansága illetve változékonysága. A következményeik közé sorolható a prudenciális szempontokkal nem törődő bankári attitűd, az ügyfelek részéről a megfontolatlan hitelfelvétel. Mindez főleg a legelső éveket jellemezte. Hamarosan azonban a piaci nyitás és a privatizációs folyamat elindulásának együttes hatására már nem a túlzott ütemű forráskihelyezés lett a baj, hanem a meglevő hitelállomány minőségének gyors romlása. Míg a „zöldmezős” beruházásként létrehozott külföldi, illetve joint-venture bankok tudatosan akviráltak ügyfeleket, az állami tulajdonú hitelintézetek megörökölték az ügyfélkört, mégpedig döntően állami tulajdonúakat, amelyek egymás után kerültek bajba fö piacaik elvesztése és menedzsmentokok miatt. A velük szembeni követelések kétessé váltak, ez pedig akkor is kikezdte volna a bankok jövedelmezőségét, majd szolvenciáját, ha kellő tőkével létesültek volna a megelőző néhány évben - de nem így volt. A romló helyzetű ügyfelektől függő bankok maguk is hamar bajba jutottak.

A gazdaságpolitikát nehéz helyzetbe hozta a hitelkihelyezés csökkenése, mert az elmélyítette a gazdaság már addig kibontakozó recesszióját. A GDP volumenindexe 1990-től négy éven át zsugorodott, és a mélypontot jelentő 1993-as évben az 1989-es esztendő 82 százalékán állt meg. A kumulált magyar csökkenés szinte teljesen megegyezik a csehszlovák és lengyel adatokkal; az utóbbi esetben a recesszió 
korábban kezdődött, és hamarabb véget ért. Tőlünk keletre és délre még mélyebb lett a tranzíciós visszaesés, és tovább tartott a rendszerváltás előtti GDP-szint elérése. Ez nálunk is egy évtizedbe telt - ami meghökkentő adat. A meglepően nagy zsugorodás több tényezőre vezethető vissza, de ezek egyike a hitelszektor hullámzó, a várakozásoktól mindenképpen elmaradó teljesítménye. A hitelszűke hatását felerősítette az állami tőkejuttatások megszünése. Segített viszont a müködőtőkebeáramlás, ezen a téren Magyarország messze kimagaslott a térségben. Akkor viszont a térség és benne Magyarország még nem részesült olyan masszív uniós transzferbeáramlásban, mint 2004-et és föleg a 2007-es hétéves uniós pénzügyi keret megnyílását követően.

A bankszektor problémái kihatottak a deficit- és államadósság-adatok alakulására is. A tőkéjüket vesztett állami bankok csődbemenetelének elkerüléséhez szükség volt a hiányzó tőke visszapótlására: a gazdaságpolitikai vezetés 1991-94 között az állami hitelintézeteket a költségvetésből tőkeemeléssel megtámogatták az úgynevezett „bankkonszolidáció” keretében. Ehhez tetemes adósságpapírt kellett kibocsájtani; ezáltal az adott évben megugrott a költségvetés kimutatott deficitje és az államadósság állománya. A makrogazdasági keresletet ugyan mindez nem növelte meg, és később az állami vagyont érintő, hasonló ügyleteket az államháztartási statisztika az elsődleges költségvetésen kívül mutatta ki, de a rendszerváltozás első három-négy kritikus évében az adós- és bankkonszolidáció tranzakciói megjelentek Magyarország makropénzügyi mutatóiban, azokat nagyban lerontva.

Bankok hasonló átmeneti kisegítésére és feltőkésítésére egyébként a fejlett világban 2008 után számos esetben volt példa. Az 1990-es években a pénzügyi közvetítőrendszer működésképességének fenntartása érdekében tett állami intervenció vitatottabb ügy volt, egyebek mellett azért is, mert a közgazdasági és gazdaságpolitikai „mainstream” akkor sokkal erősebben hatott.

\section{SZÜK NEMZETGAZDASÁGI MOZGÁSTÉR A GLOBALIZÁCIÓ CSÚCSPONTJÁN}

\subsection{A vártnál nagyobb kezdeti visszaesés okai}

A piacgazdaságra való visszatérés a térségben mindenhol nehezebbnek bizonyult, mint ahogy azt az előzetes szakmai elemzések jelezték, nem is beszélve a közvélemény várakozásairól. Hazánk és a kelet-közép-európai térség többi nemzete esetében a történelmi kitérő tartama négy évtized, az orosz társadalom számára hetven év, ez utóbbi azt is magával hozta, hogy gyakorlatilag nem élt olyan felnőtt, akinek személyes tapasztalata lett volna a piacgazdaságról. Ráadásul az a szisztéma, amelybe az érintett társadalmak több évtizednyi hiátus után visz- 
szakapcsolódtak, nagyon különbözött a múltbeli kapitalizmustól. A modern korszak üzleti viszonyairól legfeljebb azoknak lehetett ismeretük a rendszerváltozás előtti időszakban, akik külkereskedelmi vagy banki kapcsolatban álltak nyugati partnerekkel, külföldön tanultak vagy dolgoztak; ezek száma elhanyagolható volt a Szovjetunióban, és csekély a viszonylag nyitottabb szocialista országokban is. Még a külföldi diaszpóra hazatelepülö tagjai hozhattak volna magukkal élő piaci ismeretet és egyéb társadalmi tőkét.

Magyarország a rezsimváltás előtti időszakban a külső nyitottságot tekintetve aránylag kedvező helyzetűnek számított, különösen az állami és a kis számú, de létező magánvállalatok nyugati üzleti kapcsolatai révén, mégis korlátozott maradt e kör. A külföldi magyarság pedig a rendszerváltoztatás előkészítésében és kibontakoztatásában csak harmadlagos szerepet vállalt, különösen lengyel viszonyításban. A magyar gazdasági szereplők a reformszocialista évtizedekben szerzett gyakorlatuk alapján egy fokkal tájékozottabbak voltak a pénz- és áruviszonyokról, mint a merev tervgazdaságú országok lakói, ám ez az előny igen viszonylagosnak bizonyult. Az „új mechanizmus” nem tudta kellően felkészíteni a társadalmunkat a tényleges piaci működésre, mert az állami szektor szimulált piaci viszonyai és a második gazdaság, feketegazdaság sajátos ügyintézési módjai nagyon különböztek a modern és immár teljesen globalizált piacgazdasági normáktól.

A rendszerváltozást végrehajtó elit Magyarországon - és ez így volt a cseh vagy lengyel esetben is - jelentős részben értelmiségi pályákról rekrutálódott, és kiegészült a vállalati közép- és felső vezetésből közéleti pályára lépőkkel. Ezek a rétegek a társadalom egészénél jobban eligazodtak az új korszak viszonyai és a külső környezet igényei között, de természetszerüen nem lehettek felkészülve a korszak által felvetett, bonyolult ügyekre. A politikai szférában a más fejlődési pályát bejáró nyugati országokhoz képest elégtelenül voltak reprezentálva a szakszervezeti, civil szervezeti, magánvállalkozói hátterű szereplők. Az új pártoknál értelemszerűen nem állt rendelkezésre kipróbált második és harmadik vonal. Az államigazgatás központi és helyi szintjein is hiány volt a modern „civil service” igényeinek megfelelni képes tisztviselőkből.

A felsorolt vonatkozásában Magyarország nem állt rosszabbul a többieknél, de előnyt sem élvezhetett. A politikai döntéshozatal szakmaisága, hatásfoka nyilván elmaradt attól, amilyen irreálisan nagy elvárást támasztott a társadalom. Kezdettől erősen átpolitizálódtak a közügyek, éles politikai és kulturális, érzelmi hasítások szabták szét a politikai osztályt. Mindez a társadalom jelentős részében hamar lelohasztotta a demokratikus fordulathoz füződő reményeket.

Figyelemreméltó, hogy akkoriban milyen túlzott optimizmus jellemezte a nyugati közösséget. Az IMF, az Európai Bizottság, a nemzetközi szervezetek a ténylegesen végbemenőnél sokkal könnyebb átmenetet valószínűsítettek. A visegrádi négyek 
(majd hármak) az ipari termelésük ötödét vesztették el a tranzíció első néhány évében. A zöldmezős beruházások, a de novo magánvállalatok és a privatizáción sikeresen túljutó nagyvállalatok, szövetkezetek révén azután új termelési szerkezet jött létre, ám a reméltnél sokkal lassabban, a mezőgazdaság átállása pedig még elnyújtottabb lett. A Valutaalap hitelprogramjai néhány százalékos átállási recesszióval számoltak 1990-ben, ám a GDP zsugorodása a térségben mindenhol annak inkább háromszorosa, mint kétszerese lett.

A vártnál nagyobb transzformációs visszaesés tényezőinek magyarázatában máig nem egységes a tranzíció gazdaságtana. Sokan azt is megkérdőjelezik, hogy a statisztikai rendszer jól mérte-e a piacgazdaság átmenet előtti GDP nagyságát, és megfelelően regisztrálta-e a gyors átmenet során lezajló termelési és jövedelmi folyamatokat. Kétségtelen, hogy kellő megbízhatóságú és gyakoriságú nemzetgazdasági statisztikák csak 1995-től állnak rendelkezésre.

Ami a magyar ügyet illeti: a mély tranzíciós visszaesésben kimutatható egy olyan tényező, amely a 2009-es szintén súlyos (egyetlen évben csaknem 7 százalékos) GDP-esésben is megjelent: a gazdaság nagyfokú külső nyitottsága. Nagy nyitottság mellett jó világgazdasági konjunktúra esetén az európai átlagnál jóval gyorsabb a növekedés, ám dekonjunktúra idején az átlagnál nagyobb lehet a visszaesés.

\subsection{Külső gazdaságpolitikai tanácsok}

A külső nyitottság mint növekedést és átlagosnál nagyobb volatilitást magyarázó ok ugyan plauzibilis, de esetünkben rögtön felmerül a kérdés, hogy akkor gazdaságunk miért nem mutatott fel dél-koreai típusú robusztus növekedést az átállási válság után, kedvező külső konjunktúra mellett. Ehhez ki kell térnünk az 1990-es évek közgazdasági ortodoxiájára és a neoliberálisnak nevezett gazdaságpolitikai felfogás következményeire.

A washingtoni konszenzus néven közismertté váló gazdaságpolitikai „tízparancsolat” alapvetően a gazdasági populizmusra hajló latin-amerikai országoknak szólt (Willamson, 1989). Ám a „privatizálni, deregulálni, liberalizálni” üzenetet a volt tervgazdaságok is megkapták a nemzetközi szervezetektől, a nyugati kormányoktól, az akadémiai közösség nagy részétől az 1990-es években. A külső tanácsadók többsége határozott, gyors átmenetet javasolt, noha gyanítható volt, hogy a sokkterápia komoly társadalmi megrázkódtatással jár, ám ebben kevesebb kivetnivalót találtak, mint a graduális, ütemezett átmenetben. Igaz, amint a sokkterápia ismert szószólója, J. Sacks megfogalmazta, a siker további feltétele, hogy a Nyugat kereskedelmi előnyt és szükség esetén adósságkönnyítést nyújtson az „új demokráciáknak", azok pedig azonnal átveszik a haladó nyugati intézményrendszert (Sacks, 1990). 
Valójában egyik feltétel sem teljesült. A nyugati kormányok a Szovjetunió és a többi tervgazdaság technológiai szintjét eleve túlbecsülték, a demokratikus fordulat után az olcsó bérrel dolgozó keleti vállalatokat árversenyképesnek gondolták. Emiatt, meg a korábbi állami dömpingesetekre emlékezve, nem akartak aszimmetrikus (az új demokráciákat kedvezményező) külkereskedelmi rezsimet. E helyzetértékelési hibához társultak a korszak ideológiai viszonyai is. Az 1990es évtized kezdetén az állami tulajdon akárcsak átmeneti megőrzése, az állami szerkezetalakítás, a piacvédelem bármely formája szinte egyöntetű elutasításban részesült, és nemcsak az európai politikai paletta jobboldalán, hanem a szociáldemokrata kormányok részéről is. Elégségesnek látszott a nyugati jogi-piaci intézmények gyors átadása, illetve a másik oldalról nézve: az új piacgazdaságok részéről a sikeres nyugati intézmények azonnali átvétele. Ezt ugyan némelyikünk akkor is naivitásnak tartotta, mégis sokan komolyan hittek az intézményi rend egyszerű átplántálásában. A piaci fundamentalisták szerint a piacok kölcsönös megnyitása, a vállalkozások előtti akadályok határozott lebontása és a nyugati intézmények együttese garantálja a gazdasági sikert.

Mindez még a német egyesülést követő nagy csalódottság, majd az orosz gazdasági átmenettel járó káosz beállta előtti rövid időszak közvélekedése volt. Hamarosan kezdett felszínre jutni a volt tervgazdaságok váratlanul súlyos öröksége, a rezsimváltás elhúzódása, a válság valódi mélysége. A Nobel-díjat átvevő beszédében $D$. North már azt mondta ki, hogy a formális gazdasági intézmények ugyan gyorsan átemelhetők, a nem formális intézmények (szokások, társadalmi normák, gyakorlatok) átalakulása azonban sokáig tart. Beismerte, hogy a privatizáció nem általános gyógymód a gyenge gazdasági tevékenység kúrálására (North, 1993).

A gazdaságelmélet hangsúlyváltozása, a térség sajátosságait tudományos formában értelmező tranzitológia nyomán az IMF politikája is idővel átalakult, a hitelek kondicionalitása már nem volt olyan merev és egy szabvány szerinti az 1990-es évtized végétől, mint korábban. A rendszerváltozás feladatainak bonyolultságát mégis csak lassan értette meg a külvilág.

\subsection{Válságszakasz, növekedés új szerkezetben és a duális gazdaság létrejötte}

A magyar gazdaság statisztikailag mért kibocsájtása 1993 során érte el a mélypontot, és onnan még évek kellettek a tartós növekedési pályára jutásig. A térség hasonló helyzetű országaival való összevetést nehezíti, hogy a korai évek indexei némileg bizonytalanok. Azóta a statisztikai rend sokat változott, benne például a FISIM elszámolása, amely 1995 elöttre nincs visszavezetve. A KSH hivatalos éves volumenadatai és az ezek alapján számolt indexek azért adnak egyfajta képet a 
válság lefutásáról. Az 1989-es bázison a reál GDP változásai: 1990: -3,5\%; 1991: -12.1\%, 1992: -3,0\%, 1993: -0,8\%; 1994: +3,1\%, 1995: +1,5\%, 1996: +0,2\%.

A krízis negyedik évének derekán tehát növekedésre vált az index. A korábbitól már igencsak eltérő szerkezetben indult meg a növekedés, ami azonban a megszorítás nyomán kifulladt 1995 második felétől 1996-ig. 1996-ban egyébként a GDP még mindig tizenöt százalékkal maradt el az 1989-es szinttől. Ezt a hét évet érdemes a tranzíciós válság szakaszának tekinteni, amelyet majd új gazdasági szakasz követ. Az itteni szakaszolás (1990-1996) eltér a politikai ciklushoz kötődő korabeli felfogástól, amely 1994-hez vagy az 1995-ös makrogazdasági kiigazításhoz („Bokros-csomag”) köti az újabb szakaszt. Azonban az átalakulás gazdaságszerkezeti, intézményépítési és gazdasági konjunkturális jellemzői indokolják az egy szakaszként való kezelést.

Magának az 1995-ös stabilizációs csomagnak a megítélése vitatott volt és maradt. Vannak, akik dicsérik egyensúlyi hatásai miatt, mások elmarasztalják a kibontakozó növekedés lefojtásért. Megint mások inkább a hozzátapadó, neoliberálisnak tartott ideológiát ellenzik, vagy a súlyosan kedvezőtlen társadalmi (így demográfiai) következményei miatt vetik el. Utóélete is érdekes: a nemzetközi szakirodalomban gyakran hivatkoznak rá fordulópontként és a növekedési szakasz kiindulásaként, noha azt output- és beruházási adatok nem támasztják alá, ám elemei (valutaleértékelés, szociális kiadások megvágása, privatizáció újraindítása) nemzetközileg jól értelmezhető intézkedések. A baloldali koalíció (1994-1998, 2002-2010) egészében véve helyes lépésként utalt vissza az 1995-ös intézkedésekre, piacpártiságának bizonyítékaként és szimbólumaként tekintett rá. A Fidesz azonban már ellenzékben is, majd kormányon pontosan a Bokros-csomag által megtestesített, neoliberálisnak mondott iránnyal szemben határozta meg a maga gazdaságpolitikáját, különösen 2010 után.

Érdemes félretenni a kérdést, hogy érvényesült-e, és ha igen, mikor neoliberális gazdaságpolitikai irányzat hazánkban. E helyütt annyit állítunk, hogy a makrogazdasági stabilizálás az első ciklusnak a része: valamilyen költségvetési kiigazítás mindenképpen bekövetkezett volna, legfeljebb más formában, más időzítéssel és más ideológiai alapon. Ezt a tételt alátámasztja a többi rendszerváltoztató ország gazdasági folyamatainak lefutása. Az 1990-es évek tranzíciós válsága jellemzően két szakaszból állt: kezdődött általános termeléscsökkenéssel, és ekkor romlottak az egyensúlyi mutatók, megnőtt a költségvetési hiány a bevételi források gyengülése és az átalakulás miatti, egyszeri kiadási tételek megugrása nyomán, valamint gyorsult az infláció. Így pedig a tranzíciós válság második szakaszában, annak szerves részeként szükségessé vált a makrogazdasági stabilizálás.

Az viszont országonként eltérő formát öltött. A lengyel átmenetben például nem az állami költségvetés vált kritikus üggyé, hiszen az állam a megelőző, vergődő évek során sokat leadott jóléti szerepéből, és mind kiadási oldala, mind mérleg- 
hiánya kisebb volt a magyarországinál. Inkább vágtató inflációban öltött testet az egyensúlytalanság, 1993 során négy nullát kellett levágni a zlotyból a fizetőeszköz renominálása során. Magyar viszonyok között a pénzromlás sosem ért el ekkora mértéket. Az 1991-es magyar inflációs csúcsot dezinfláció követte 1994 végéig, amikor a pénzromlás üteme 17 százalékra mérséklődött. Majd az 1995-ös stabilizációs csomag hatására ismét 30 százalékhoz tartott a fogyasztói árindex, és onnan lassan ereszkedve vált egy számjegyűvé.

A forintvaluta összes pénzfunkcióját végig sikerült megőrizni az átmenet során. Mégis kimondható, hogy a magyar közgondolkodásban az árstabilitás mint cél nincs mélyen beágyazódva, annyira semmiképp, mint például a cseh felfogásban. A fiskális fegyelemre is igaz az állítás: a magyar költségvetési hiány az áttekintett időszak egészében nagyobb, mint Csehországban. Különösen feltűnő a hiány volatilitása, mégpedig a politikai ciklus évei szerint: a választási éveinket rendszeresen nagyarányú deficittel zárták a kormányok az első két évtizedben. Ennek egyik következményeként a magyar állam rekordidőt töltött az EU többlet-hiány eljárása alatt egészen 2013-ig. Onnantól viszont a GDP 3 százalék alatti deficithányad jószerével az egyetlen fix gazdasági mutató, holott közben a gazdasági ciklus markánsan változott. Az ok sajátosan politikai: a kormány ügyel arra, hogy az uniós határérték alatt maradjon a GDP-arányos hiány, és ezzel távol tartsa az Európai Bizottságot.

Az 1990-1996-os időszak egyetlen szakaszként való kezelése mellett szól az is, hogy ekkor zajlik le gazdasági szerkezetünk radikális átalakulásának zöme. Bár a magyar makrogazdasági átmenetet a visegrádiakhoz, baltihoz, oroszhoz viszonyítva graduálisnak tekinti a külföldi szakirodalom (eléggé felületes statisztikai alapon és névértéken elfogadva más kormányoktól a radikális átmenetről szóló megnyilatkozásokat), a mikrogazdasági tények azonban mást mutatnak. A szerkezeti átalakulás gyorsasága terén Magyarország kiemelkedett. A tőkebeáramlás, a vállalatalapítás adatai, a csőd- és felszámolási törvénykezés, a pénzügyi közvetítőrendszer átalakulása, a munkatermelékenység növekedése alapján jól látható, hogy a szerkezeti és intézményi átalakulásban Magyarország vezetett. Máshol sokkal több kompromisszummal és rejtett hibákkal zajlott a gazdasági élet modernizációja. A cseh gazdaságban az 1990-es évtized végén felszínre is kerültek a kuponos magánosítás káros mellékhatásai, különösen a vállalatkormányzás gyengeségei, amelyek belejátszottak az 1997-98-as recesszióba. A 2000-es évek elején pedig a lengyel gazdaságnak kellett szembenéznie olyan iparszerkezeti örökségekkel, amelyekhez hasonlókat hazánk már az előző évtizedben felszámolt. Hasonló utókrízis érte el Szlovákiát az 1990-es évtized végén a privatizációs politika, vagy még inkább annak hiánya következtében.

Ezekhez mérve a magyar gazdaság szerkezeti modernizációja a legerősebbnek számított. Ám ezzel elsőként nálunk vált markánssá a dualitás, az tehát, hogy lé- 
tezik egyfelől a külföldiek által dominált, tőkeerős szektor, mellette pedig a hazai magántulajdonú második szektor, valamint a maradék állami tulajdon: ez utóbbiakban a munkatermelékenység, a tőkehatékonyság jóval kisebb. Valójában nem annyira dualitásról, mint inkább egymás mellett párhuzamos működő fragmentumokból álló gazdaságról kell beszélnünk.

\section{GAZDASÁGPOLITIKAI MOZGÁSTÉR KÖZEPESEN FEJLETT, MEGOSZTOTT SZUVERENITÁSÚ ORSZÁGBAN}

\subsection{A privatizáció és a tőkebevonás mint strukturális politika}

Az első évtized nagy megrázkódtatásai után gazdaságunk saját potenciáljához képest erős növekedést mutatott fel. 1997-től a GDP bővülése 2006-ig, csaknem egy évtizeden át meghaladta az uniós átlagot, így a történelmi mércének tekintett országokhoz némileg közeledtünk. Azt azonban akkor is lehetett tudni, hogy a növekedési ütemet a központi kormányzatra, az önkormányzatokra és a háztartásokra egyaránt kiterjedő eladósodás tolta a természetes növekedési ráta fölé. Mindezzel együtt továbbra is a közepes gazdasági fejlettségi szinten maradt Magyarország, ám eközben a statisztikai átlagot kitevő résztényezők szóródása megnőtt.

A nemzetgazdasági átlag eleve elfedi a már említett gazdaságszerkezeti dualitást, amely a magyar közvéleménybe a multik problematikájaként került be, noha a szóban forgó szereplő gyakran nem többnemzetiségű cég, hanem külföldi nagyvállalat: német vagy japán autógyár, amerikai elektronikai cég, svájci élelmiszeripari konszern, belga bank. A nemzetközi tőkeáramlások a maguk sajátos logikája miatt megnövelték az ország központi térsége és az attól földrajzilag (de inkább infrastrukturálisan) távolabb fekvő térségek közötti aktivitási és jövedelmi szintkülönbséget.

Ez a tény erőteljes területfejlesztési politikát igényelt volna, és szükségessé tette volna, hogy az állami erőforrások elosztásában érvényesüljön a regionális aspektus. A kormányok azonban - egészen az uniós fejlesztési források 2007 utáni megsokszorozódásig - nem rendelkeztek komoly anyagi erővel. A területfejlesztés mint gazdaságpolitikai szakmai ágazat akkor kapott átmeneti időre nagyobb figyelmet, amikor az uniós csatlakozásra való felkészülés keretében a területi beosztás (NUTS) új kategóriáival kellett foglalkoznia a politikai vezetésnek. E szakasz lezárultával azonban csökkent a politika érdeklődése, majd a gazdaságpolitika centralizációs jellegének erősödése miatt háttérbe szorult a területi aspektus. A kormányzati szerkezetből régóta hiányzik a terület- és településfejlesztés minisztériuma; a szakapparátussal ellátott kormányszervek hiányát nem pótolják az 
alkalmi miniszterelnöki megbízottak vagy a választás előtti időszakban tett helyi fejlesztési ígéretek.

Ami viszont folyamatosan benne van a gazdaságról és gazdaságpolitikáról szóló diskurzusban, az a magyar tulajdonú kis-és közepes vállalkozások ügye. Mindmáig gondot okoz a kkv-szektor gyenge munkahelyteremtö képessége, az elégtelen beruházási aktivitás, a fejletlen bankkapcsolat, a menedzsment gyakori fogyatékossága. Ez sem magyar sajátosság: a közepes fejlettség tényéből objektíve adódik az igény az e szektor különös viszonyainak megfelelő szakpolitikára. Ilyen törekvés kezdettől megjelent a kormányzati programokban, kezdve az első időszak privatizációs és egzisztenciahiteleinek a konstrukcióival, majd folytatódott a beszállítói programok meghirdetésével, a klaszterkoncepcióval, az ipari parkok propagálásával, az időszak végén a Széchenyi-kártyával. Idővel az EU-források felhasználási céljai közé került be hangsúlyosan a kkv-k versenyképességének javítására. Mégis, három évtizedet tekintve is látszik e programok legfeljebb közepes hatékonysága. Ugyanez mondható el az időnkénti iparszerkezeti, struktúrapolitikai állami programok érvényre jutásáról.

A szakpolitikák között a nyugati gazdaságokban erőteljesen szokott megjelenni a jövedelempolitika. E téren is nagyon különbözik hazánk, bár elmaradásunk sokféle oka között van általános, térségi jellegű is. A közepes fejlettséggel gyakran együtt jár a reálbérszint stagnálása, a vállalati nyereségráta magas szintje, vagy másképpen, a nyomott nemzetgazdasági bérhányad áll szemben a magas profithányaddal. A nyomott magyar bérszint egészen a legutóbbi időkig fennállt, és nehezítette a hazai piactól függő szolgáltató és termelő kis- és középvállalatok pozícióit. A nyugatitól roppant mód elmaradó bérszint az EU-tagság elnyerése elött, sőt egészen a főbb partnereink által kért munkaerőpiaci derogáció lejártáig, 2011-ig nem vezetett a munkavállalók tömeges külföldre áramlásához. Addig inkább volt társadalmi opció a korai nyugdíjba menetel vagy a második (informális) gazdaságba süllyedés. A magyar inaktivitási hányad magas szinten beragadt a tranzíció második évtized elején, erőteljes gazdasági növekedés mellett. Ez bizony komoly gazdaságpolitikai hibaként azonosítható: a 2006-ig terjedő expanzió alatt lett volna jó esély a foglalkoztatási aktivitás növelésére.

Az állami szociál- és gazdaságpolitika akkori erőtlenségére adott válaszként is felfogható a 2010 utáni fordulat a munkaügyi politikában. Elemei között megtalálható a korai nyugdíjazással szembeni kormányzati fellépés, a közmunkaprogram kiszélesítése és a Belügyminisztérium alá helyezése. A program révén jelentősen javultak a magyar munkaügyi adatok. A tényleges foglalkoztatási hatást illetően a kép bonyolultabb. A közmunka-intézkedések egyik ígérete szerint az inaktivitásból kiemeltek körében megnő az értékteremtő munka világába való visszalépés esélye - ez még várat magára. A program szociálpolitikai kritikusai pedig azt állítják, hogy a közmunka intézményének kiterjesztése a tartósan mun- 
kajövedelem nélküli, elsősorban vidéken koncentrálódó, leszaladt rétegek központosított ellenőrzését is szolgálja. Okkal szerepel az Európai Bizottság 2018-as országspecifikus ajánlásaiban a közmunkaprogram átalakítása, értelmes folytatása aktív munkaerőpiaci intézkedésekkel, hogy visszakerülhessenek a munkaerőpiacra a közmunkán levők.

A munka világának szabályozása, így A munka törvénykönyve 2012-es változtatásai, a nagy ellenállást kiváltó 2018. végi túlóraszabályozás reagálás annak a gazdasági struktúrának az igényeire, amely az itt elemzett időszak első felében kiépült: nyugati (nagy)vállalati technológia és tőke kombinálódik a rendelkezésre álló, képzett munkaerővel. A munkaerő-tartalékok felszívódásával és a külföldi munkavállalás felgyorsulásával azonban az adott szerkezeten belül már egyre nehezebb fenntartani a termelésnövekedési dinamikát - ez a következő évek egyik legnehezebb gazdaságpolitikai kihívása.

\subsection{Az uniós források elköltése mint struktúra- és konjunktúrapolitika}

A tranzíció előrehaladtával egyáltalán nem gyengült a külső korlátok hatása, de már nem az IMF a maga hitelkondícióival az, amely keretek közé szorítja a nemzeti gazdaságpolitikát (eltekintve a fizetésképesség megingásának pillanataitól, mint Magyarország esetén 2008-ban). Ami nehezíti a hazai tulajdon megerősítését vagy a területi aránytalanságok kordában tartását célzó szerkezeti politikák folytatását, az inkább a nemzetközi konvenciók és integrációs tagságok léte. Ezek esetében a távlati célok érdekében vállalt önkorlátozásról is beszélhetünk, mégis adott pillanatban a döntési szabadságának szűkülését érzékeli a kormányzat. A magyar gazdaságpolitika számára fontos mérföldkő volt a belépés 1996ban az OECD-be, ezáltal a tagországok vállalatai hazai elbánásban részesülnek Magyarországon a magyar cégek hasonló kedvező elbánása fejében. Mindez másfelől szűkítette az autonóm állami szerkezeti politikák mozgásterét.

Még szigorúbb szabályokkal járt az EU-tagság, kezdve már a tagjelölti időszakkal. A korábban strukturális, később kohéziós nevet viselő felzárkóztatási szakpolitikákat az uniós szervezetek és a tagállami kormányok közösen dolgozzák ki, a végrehajtásban tág cselekvési tere marad a helyi tényezőknek. Mégis a hatalmas források, azok elkötésének időbeli kötöttségei, felhasználási szabályai a magyar gazdaság számára erős külső meghatározottságot jelentenek, és terelik-korlátozzák a gazdaságpolitikát. Az uniós normákba nem fér bele a hazai nagyvállalatok („nemzeti bajnokok”) közvetlen fejlesztése állami eszközökkel, az ilyen kísérletek szükségszerüen beleütköznek a versenyszabályokba és az állami támogatás tilalmába, amint azt a magyar kormánnyal szembeni számos kötelezettszegési eljárás jelzi. A magyar kkv-támogató programok viszont jórészt kompatibilisek az uniós 
normákkal, és ezek sikeres megvalósítása inkább múlik a magyar adminisztrációs, projektirányítási képességeken, mint külső jogi-intézményi tényezőkön.

Az EU-ból beáramló nettó forrásmennyiség rendkívül erős hatással járt (és ameddig ez a nagyságrend marad, járni is fog) a magyar gazdaság egyensúlyi mutatóira. Az időszak második felében évente abszorbeált devizaforrás (átlagban a GDP 3 százaléka) felgyorsította a nettó külföldi tartozások leapadását, részben tehermentesítette a központi költségvetést, magas szinten stabilizálta az agrárszektorban a jövedelmeket. Egészében jelentősen megemelte az aggregált keresletet, és ez - különösen a 2008 utáni időszakban - nagyon sokat segített abban, hogy a gazdaság negatív kibocsátási rése bezárulhasson. Azt viszont még nem látni világosan, hogy az uniós források (a KAP és a kohéziós politika programjai) miként növelik a gazdaság kínálati oldalát és ezzel a későbbi időszak növekedési potenciálját.

\subsection{Szuverenitás és kormányzati mozgástér}

A három évtizedes időszakban kritikus fordulatot hozott Európa és benne Magyarország számára a 2008-as pénzügyi válság, amelynek következményeképpen megtorpant az 1980-as években kibontakozó globalizációs hullám. Míg a volt tervgazdaságok előtt álló gazdaságpolitikai pályákat igen erősen determinálták a külső feltételek az 1990-es években, majd az európai integráció párhuzamosan folyó bővítése és mélyítése volt az, ami beszűkítette a manőverezési teret a kis nyitott piacgazdaságok kormányai számára, a válság új helyzetet teremtett. Magyarország esetében felszínre került nagyfokú külső kitettsége, amely miatt 2008ban a szocialista-szabaddemokrata kormánynak az IMF és az EU pénzügyi védőszárnya alá kellett bemenekülnie. Ám különös módon a gyors lefutású pénzügyi válságot követően a korábbinál sokkal tágabb tér nyílt meg a saját út követői előtt. Valójában addig sem volt helytálló az a gyakran hangoztatott állítás, amely szerint a globalizált világban a nemzetállam elveszti jelentőségét, és a világpiacba való bekapcsolódás minden országra azonos mintákat kényszerít rá. A piacgazdaság domináns magánszektora valóban szorosan integrálódik a külvilágba, és a kisebb belpiacú országok magánszektorának különösen nagy a külső kitettsége, ám a vegyesgazdaság közösségi szektora is komoly kiterjedésű, erősen kötődik a helyi politikához. Az európai államok a GDP felének megfelelő összegeket futtatnak át a költségvetésükön, sőt az uniós transzferek nagy része is átmegy az államon, és eszköze lehet a gazdaságpolitikának.

A tagállami szabadságfok léte megnyilvánult a 2008-as pénzügyi, majd a 2010-es eurózóna-válságban. Az európai magállamok egy része Németország vezetésével a pénzügyi stabilizálást szorgalmazta, míg számos állam a periférián nem tudta 
vagy nem kívánta ez azt utat járni. A magyar gazdaságpolitika önértékelése is az, hogy eltér a (nyugat-)európai gazdaságpolitikai ortodoxiától. A fordulat nem egyedülálló és nem is meglepő, hiszen tudható, hogy a gazdaságfejlődési sikertörténetek zöme egyedi stratégiák nyomán állt elő, miként korábban az ázsiai modernizációs esetekben. Ezek másolhatóságát természetesen rontja, hogy más fejlettségi szinten és kulturális térben zajlottak le, mint amilyen körülmények az erőltetett iparosításon átesett kelet-közép-európai országokat jellemezték modellválasztásuk történelmi pillanatában. Egyikük sem választhatta volna a 20. század végén az ázsiai fejlesztési állami modernizációs pályát, de maradt abban szabadságfok, hogy a globalizációs folyamatba milyen egyéni alkalmazkodási technikákkal kapcsolódjon be egy ország.

Amint a monetáris szuverenitáshoz való viszonyulás példája mutatja, még a viszonylag homogén V4-csoportban is eltérő stratégiákat követtek: Szlovákia korai időpontban csatlakozott az euróövezethez, a többi három ez ideig nem. A csatlakozás mellett üzleti, gazdasági érvek szólnak, ezekkel monetáris-politikai indoklást szoktak szembeállítani, de tudott, hogy a szuverenitás politikai szempontjai legalább annyira meghatározóak. A bankunió ügye is megmutatta: a gazdasági racionalitás ismérveiből nem vezethető le egyértelműen, hogy valamely ország (pl. Románia) miért kíván csatlakozni, míg egy másik, így Magyarország miért nem - a választ inkább a hatalmon levő politikai erők sajátos szempontjai adják meg.

\subsection{Nem szokványos gazdaságpolitikai pálya a válság után}

A magyar gazdaságpolitikai gyakorlat tartalmi elemzése (ami tehát eltér az érintett kormányok deklarációitól, hivatalos megnyilvánulásaitól) az egymást váltó szakaszok esetében jól kimutatható egyéni vonásokat tartalmaz, amelyek a követett gyakorlatot megkülönböztetik a korszak uralkodó irányzatától (ortodoxiájától), valamint a hasonló helyzetű országok aktuális kurzusától. Ugyanakkor általános trendek is felmutathatók, hiszen a magyar gyakorlat sok hasonló hatás alatt formálódik.

Itt nincs tér a különféle szakaszok áttekintésére, különösen az egymást követő kormányok szakpolitikai mixtúrájának elemzésére. Egyébként még adott politikai cikluson belül is megkülönböztethetők eltérő időszakok; az Antall-kormány az erőteljes kezdeti intézményépítési erőfeszítéseit a német ihletésü szociális piacgazdasági irányzat melletti elkötelezettség ihlette, de a ciklus közepén már a szerkezeti válság kezelése dominálta a gazdaságpolitikai mozgásokat. A Hornkormány a kezdeti bizonytalanságot követően makrostabilizálást hajtott végre, és olyan széleskörü privatizációba fogott, amely még közüzemeket is magában 
foglalt (ez utóbbiak zömét visszaállamosították 2010 után), majd a választásokhoz közeledve költségvetési expanziót indított el. Az első Orbán-kormány az 1998-as világgazdasági turbulenciákra is tekintettel fiskálisan konzervatív politikával indított, majd a ciklus közepén váltott a kínálati oldalú irányba.

Ilyen és hasonló szakaszváltások sürűn mutatkoznak a teljes időszak során. Részben a politikai vezetés szándékait tükrözik (választások előtti költségvetési lazítás), máskor pedig inkább a külső kényszerek és hatások következményeként állnak elö. Ilyen éles fordulat következett be 2006 nyarán, amikor az évek óta tartó és nagyarányú költségvetési deficitbe torkolló kormánypolitikának vetett véget az Európai Tanács, amely a Stabilitási és Növekedési Paktum sokadik megsértését akkorra elégelte meg. Az uniós szabályok szigorodása-enyhülése maga is bizonyos ciklikusságot mutatott, amely hol keresztezte, hogy felerősítette a magyar hazai üzleti-kormányzati ciklust.

További külső ciklikussági tényezőként hatott az uniós alapok beáramlása, amely technikai és adminisztratív okokból meglehetősen volatilis, és emiatt erős kilengést vihet az aggregált kereslet alakulásába. Ami viszont az uniós forrásoknak az összkínálathoz való hozzájárulását illeti, még nincs elégséges ismeretünk, de a forrásfelhasználás hatékonyságát bizonyosan rontja gazdaságunk abszorbeálási képességének gyengesége, az uniós források elköltésénél kimutatható túlárazás, a folyamat kampányszerüsége és gyakran változó adminisztratív háttere.

A 2008 utáni időszak könnyebbé tette a nem szokványos gazdaságpolitikák folytatását azokban az országokban, ahol eleve nem volt erős a külső pénzügyi függés, vagy idővel mérséklődött. Ez utóbbi a magyar helyzet, több tényező egy irányú hatására: 2009-re masszív kiviteli többletbe fordult a külkereskedelem, az uniós források bővülő mértékben áramlottak be 2007-et követően, majd nagyot nőttek a külföldön munkát vállalók hazautalásai. Mindezek révén külön intézkedések nélkül is mérséklődött volna a nettó külföldi tartozás, és erre még rá is erősített a költségvetési politika, valamint a monetáris politika és szabályozás.

2010-től a szuverenitás visszaszerzésének politikáját meghirdetve, új gazdaságpolitikai utakat keresett a magyar kormány. A motívumok között bizonyosan megtalálható az a felismerés, hogy a társadalom nagy részének konvergenciavárakozásai nem teljesültek, és megerősödött a biztonság iránti igény. A nemzeti érdek hangsúlyozása, az EU intézményeivel, az IMF-fel és a nemzetközi tőke megtestesítőivel szembeni fellépés politikailag sikeresnek bizonyult, noha a társadalom nagy része tudatában van az uniós tagságból fakadó előnyöknek. Miután azonban a pénzügyi válság és az azt követő, nehéz fél évtized élményei alapján sokak fejében a teljes rendszerváltási folyamat kudarcként jelenik meg, az addig uralkodó nyugati társadalmi-gazdasági modelltől való elfordulás jól kommunikálható széles rétegek elött. 
$\mathrm{Az}$ áttekintett időszak második felében a magyar gazdasági növekedési és konvergenciateljesítmény a térséghez mérve szerény eredményt hozott, holott egészében igen kedvező nemzetközi körülmények álltak fenn: történelmileg rekordalacsony nemzetközi kamatláb, az időszak nagy részében javuló nemzetközi cserearányok, tekintélyes transzferjövedelem az Európai Uniótól, és legfőképpen a magyar kivitel számára igen fontos közép-európai térség húzóhatása. Néhány tényező azonban visszafogta a dinamikát. Ami a térség országaihoz mérve igen feltűnő: a magyar állam által elvont jövedelem aránya. A centralizációs ráta megközelíti, sőt esetenként meghaladja a fejlett kontinentális jóléti államokét, jóval magasabb a sokkal nagyobb közepes jövedelmű európai országokénál.

A nem szokványos gazdaságpolitikai döntéseket, és különösen a gyors, rögtönzésszerű intézkedéseket nehéz követni a gazdasági szereplőknek, föleg a külföldieknek. Erre utal az országkockázati besorolások alakulása. Ahogy a Fitch 2018. tavaszi értékelése fogalmaz: a gazdaságpolitikai kurzus hitelességi kérdőjelei, a kiszámíthatatlan intézkedések lefelé módosítják a modellszámításokból adódó besorolást $(\mathrm{BBB}+)$, így csak $\mathrm{BBB}-\mathrm{a}$ szuverén kockázat besorolása. A nemzeti vállalkozói réteg megerősítését célzó intézkedések pedig az uniós versenyjogi és általános jogi normákkal ütközhetnek. Bár elképzelhető olyan irányvétel az európai együttműködésen belül, amely a tagállami különutas politikák előtt szélesebb utat nyitnak egyszerűen a válság után változatosabbá váló nemzeti programok tudomásulvételével, de annak ellenkezőjét is hozhatja az európai politikai dinamika, amely az adópolitika, szociális rezsimek területén szorosabb egyeztetést, valamint az eurózónához kötődő intézmények súlyának növekedését hozza, és ezzel megnöveli a saját út követésével járó gazdasági kockázatokat.

\section{ZÁRÓGONDOLATOK}

Az áttekintett három évtizedet az 1989/1990-es radikális politikai változásai és a 2019-es év szintén igen mozgalmas társadalmi-politikai eseményei fogják keretbe egész Európa és benne Magyarország számára. Így a magyar gazdaságpolitika sajátosságait, belső tendenciáit nehéz kimutatni, elkülönítve a fejleményekben a külső meghatározó tényezőket.

Az időszak elején a gazdaságpolitikai erőfeszítések elégtelenül monetizált, erőteljesen iparosodott, sokféle egyensúlytalansággal küzdő gazdaságra irányultak. Az időszak végpontján sokkal jobb egyensúlyi helyzetű, immár kifejlett piacgazdaság szolgált keretül a gazdaságpolitikai cselekvéshez. A korszak kezdetén a korábbi fó piacokra való visszatérés és a Nyugat intézményi-politikai rendszeréhez való végérvényes visszacsatlakozás volt a domináns törekvés, amelynek alárendelődtek a szakpolitikai fejezetek. A gazdaságpolitizálás adatbeli, intézményi és 
politikai feltételei roppant gyorsan változtak: kezdetben rendkívüli tervezési bizonytalanság közepette kellett a szakpolitikákat kialakítani és végrehajtani, mára nálunk is kifejlődött az uniós nomenklatúra szerinti információs rend.

Az első évtized közepére kialakuló belső intézményi rend, a magántulajdon túlsúlya, a szilárd biztonság- és kereskedelempolitikai lehorgonyzottság mellett felgyorsultak és az évtized végére lezajlottak a nagy termelési-ágazati szerkezetátalakulások, létrejöttek azok a termelési kultúrák, amelyek az output, a kivitel és a foglalkoztatottság szempontjából karaktert adtak a magyar gazdaságnak. A nagyfokú külkereskedelmi és pénzügyi nyitottság mellett a magyar gazdaságpolitika öröknek látszó dilemmája (növekedés vagy egyensúly) elvesztette addigi relevanciáját. Úgy nézett ki, hogy a nyugati értékláncokba való bekapcsolódással és a reánk is érvényes uniós normák és döntési szabályok követésével a nemzeti gazdaságpolitika másodrangú kockázati tényezővé szürkül, és nincs ok annak a megkérdőjelezésére, hogy a társadalom által várt jövedelmi konvergencia folyamatosan és érezhetően előrehalad.

Ugyanakkor érzékelhettük, hogy a régi gondok közül számos fennmaradt. Ilyen az inflációra és a költségvetési hiányra való hajlam, igen sokáig a munkaerö területi és szakmaközi mobilitásának gyengesége, az állami paternalizmus elfogadása, sőt igénylése. A pénzügyi válságot megelőző években az egyensúlytalanságok ismételten kifejlődtek: így fordulhatott elö, hogy az OECD és az EU tagjaként Magyarországnak - igaz, nem egyedül Európa peremén - hosszú évek után újra az IMF-hez kellett fordulnia. A kormány ezzel kénytelen volt elfogadni döntési szuverenitásának beszükülését egy olyan időszakban, amikor az európai projekt zavarai Magyarországon is, máshol is a nemzeti retorika erősödését, a különutas megoldások felé fordulást hozták.

Magyarország pénzügyi piacainak müködése szempontjából hasonlóan sokféle alszakaszból, fordulópontokkal megtört folyamatokból állt a három évtized. A magyar pénzügyi rendszer a másokhoz képest néhány évnyi indulási előnnyel a háta mögött sem tudta az 1990-es években elkerülni a megrázkódtatásokat, bankcsődöket és botrányokat. Rövid időn belül ugyanúgy külföldi tulajdoni többségűvé vált, mint a más elóéletű, volt szocialista országok többségében. Az időszak végére a pénzügyi mélységet illetően Magyarország ugyanúgy elmarad az uniós átlagtól, mint a hasonló hátterü nemzetek, de a válságon túljutva, ütésállóbb lett a hitelintézeti rendszer. Az a remény viszont, hogy Budapest legalább regionális érvényü pénzügyi központként emelkedjen ki, nem vált valóra. Logisztikai központként - köszönhetően a politikailag is motivált infrastruktúra-fejlesztéseknek, de leginkább gazdaságföldrajzi fekvésünknek - inkább van esélyünk a térségben. Átgondolt és kellő anyagi erővel támogatott szerkezeti programok híján leginkább az EU-csatlakozási, majd az EU-támogatási programok, valamint a privatizációs és tőkebevonási ügyletek formálták a gazdasági szerkezetet. Ezt a terme- 
lési struktúrát erősen érinti (egyszerre veszélyezteti és potenciálisan gazdagítja) a digitalizáció és automatizáció folyamata. A következő évek mutatják meg, hogy a magyar gazdaság mit profitál az új esélyeket hozó változásokból. Az is a közeljövő kérdése, hogy az időközben nagyra nyíló területi és társadalmi aránytalanságokra, a humán tőkeképződés már szembetűnő hiányosságaira miként reagál a szociál- és területi politika, a kutatási és fejlesztési politika, az oktatásügy és a társadalmi inklúziót szolgáló intézményrend.

\section{HIVATKOZÁSOK}

Bod PÉTer Ákos (2014): Nem szokványos gazdaságpolitikák. Budapest, Akadémiai Kiadó.

EC (2018): European Commission: Recommendation on the 2018 National Reform Programme of Hungary. Brussels, 23.5.2018, COM(2018) 416 final, https://ec.europa.eu/info/sites/info/files/2018european-semester-country-specific-recommendation-commission-recommendationhungary-en.pdf.

North, Douglass C. (1993): Economic Performance through Time (Nobel Prize Lecture). Lecture to the memory of Alfred Nobel, December 9, https://www.nobelprize.org/prizes/economicsciences/1993/north/lecture/.

SACKs, JefFrey: What is to be done? The Economist, Jan 13. 1990.

Williamson, J. (1989): What Washington Means by Policy Reform. In John Williamson (ed., 1990): Latin American Adjustment: How Much Has Happened? Chapter 2, Peterson Institute for International Economic, published April 1990. 